\title{
ОПЫТ ВЕДЕНИЯ ДЕТЕЙ С ПРЕЖДЕВРЕМЕННЫМ ПОЛОВЫМ РАЗВИТИЕМ В МОСКВЕ
}

\author{
1,2ВоронцоваИ.Г., ${ }^{1,2}$ Петряйкина Е.Е.
}

${ }^{1}$ ОСП Российская детская клиническая больница ФГАОУ ВО РНИМУ имени Н.И. Пирогова Минздрава России

${ }^{2}$ ГБУЗ «Морозовская ДГКБ ДЗМ»

\begin{abstract}
Введение. Преждевременным половым развитием (ППР) считается появление вторичных половых признаков до 8 лет у девочек и до 9 лет у мальчиков.

Распространенность ППР зависит от нозологического варианта синдрома, пола и возраста ребенка. Гонадотропинзависимые (центральные) формы ППР у девочек встречается значительно чаще, чем у мальчиков. По литературным данным, распространенность центральной формы ППР в мире у девочек до 2 лет составляет 0,5 случаев на 10000 детей, от 2 до 4 лет - 0,05 на 10000, от 5 до 9 лет - 8 на 10000. Среди мальчиков ППР встречается реже, вне зависимости от возраста: 0,05 на 10000
\end{abstract} (1).

Преждевременная половая зрелость центрального происхождения (ППР центрального генеза) - код по МКБ-10: Е22.8, входит в Перечень жизнеугрожающих и хронических прогрессирующих редких (орфанных) заболеваний, приводящих к сокращению продолжительности жизни граждан или их инвалидности.

Данные о пациентах, страдающих ППР центрального генеза, вносятся в Федеральный регистр лиц, страдающих жизнеугрожающими и хроническими прогрессирующими редкими (орфанными) заболеваниями, приводящими к сокращению продолжительности жизни граждан или их инвалидности, и его регионального сегмента, правила ведения и подачи сведений в который утверждены Постановлением Правительства РФ от 26 апреля 2012 года № 403.

Профильные материалы московского регионального сегмента Федерального регистра лиц, страдающих жизнеугрожающими и хроническими прогрессирующими редкими (орфанными) заболеваниями, приводящими к сокращению продолжительности жизни граждан или их инвалидности, анализируются в представленной статье.

Материалы и методы. По представленной ГБУ «Научно-исследовательский институт организации здравоохранения и медицинского менеджмента Департамента здравоохранения города Москвы» информации на 01.01.2021 г., количество прикрепленного детского населения города Москвы составило 2069696 человек, из них количество детей и подростков, страдающих эндокринной патологией - 82326 человек, что составляет 4\% от общего количества детского населения города Москвы.

Проанализированы данные по Москве регионального сегмента Федерального регистра лиц, страдающих жизнеугрожающими и хроническими прогрессирующими редкими (орфанными) заболеваниями, приводящими к сокращению продолжительности жизни граждан или их инвалидности: на 01.10.2021 г. количество детей с ППР центрального генеза (Е22.8), находящихся на диспансерном учете в поликлиниках Департамента здравоохранения города Москвы (ДЗМ), составляет 204 пациента (из них 186 девочек и 18 мальчиков), данные регистра ежедневно обновляются, в связи с завершением или стартом терапии.

Результаты и их обсуждение. Таким образом, распространенность ППР центрального генеза в Москве на 1.10.2021 г. по данным профильного регистра составляет 1 на 10000 детского населения без учета пола. За последнее время отмечается тенденция к увеличению количества пациентов с впервые установленным диагнозом ППР центрального генеза: за 2020 год диагноз ППР центрального генеза был установлен 47 пациентам (45 девочек и 2 мальчика), что больше на 57,4 \% по сравнению с данными за 2019 год, когда количество детей с впервые выявленным ППР составило 27 пациентов (25 девочек и 3 мальчика). 
Проанализированы данные 50 детей с ППР центрального генеза, которые завершили терапию пролонгированным аналогом гонадотропин-релизинг гормона (ГнРГ). В представленной группе детей - 45 девочек и 5 мальчиков.

Из 50 человек у 49 была проведена стимулирующая проба с ГнРГ (одному ребенку установлен диагноз без проведения проб, в связи с полученными данными базальных гормонов в пубертатных значениях), в данной группе детей максимальный выброс на пробе с ГнРГ - ЛГ составил более 100,0 МЕ/мЛ.

По данным МРТ головного мозга у 18 человек (36\%), выявлены изменения: у 3 девочек обнаружена микроаденома гипофиза, у 10 девочек объемные образования головного мозга (арахноидальные кисты хиазмально - селлярной области и дна 3-го желудочка, у 1 мальчика - глиома), у 3 девочек и 1 мальчика - гидроцефалия, расширение боковых и 4-го желудочка головного мозга, 1 мальчика органическое поражение ЦНС, у 32 человек (64\%) - патологии не выявлено.

Средний возраст верификации ППР центрального генеза и старта терапии в группе детей, завершивших лечение в 2021 году, у девочек - 6 лет 7 месяцев, средний костный возраст (КВ) при этом - 9 лет 6 месяцев; у мальчиков - 7 лет 9 месяцев, средний КВ 13 лет 5 месяцев.

Средний возраст детей с ППР центрального генеза на момент завершения терапии: девочки 10 лет 6 месяцев, средний рост 150,4 см; мальчики - 12 лет 6 месяцев, средний рост 153,1 см. Соотношение КВ к хронологическому возрасту и у мальчиков, и у девочек составило 1,0. Это свидетельствует об эффективности терапии - торможении прогрессии КВ и достижении его соответствия хронологическому (паспортному) возрасту с улучшением ростового прогноза.

Заключение. В настоящее время не существует четких критериев, определяющих сроки окончания терапии, каждый случай требует персонифицированного подхода к пациенту в рамках оценки всего патологического симптомокомплекса, который позволяет врачу - детскому эндокринологу определить оптимальный срок старта терапии и ее завершения для данного пациента, согласно актуальным клиническим рекомендациям. Это достижение пубертатного возраста (девочки - 10-12 лет, мальчики - 11-13 лет); достижение костного возраста 12-13 лет для девочек, 14 лет для мальчиков; снижение скорости роста менее чем до 2 SD для данного костного возраста; достижение роста, соответствующего костному возрасту (конечный прогнозируемый рост, близкий к целевому); психологическая готовность ребенка и родителей. Хирургическое или лучевое лечение объемных образований головного мозга у детей с ППР проводится только по неврологическим показаниям, определяемым нейрохирурургом. Гонадотропинзависимое ППР хорошо поддается терапии аналогами ГнРГ пролонгированного действия вне зависимости от нозологического варианта и не является показанием к хирургическому лечению (1). Представленные критерии завершения терапии соответствовали данным по прекращению лечения детей с ППР центрального генеза в Москве.

Полученные данные о количестве детей (36\%), с изменениями по данным МРТ головного мозга, свидетельствуют о том, что лечащему врачу специалисту, необходимо проявлять настороженность при оценки полового развития детей в допубертатный период, это необходимо, прежде всего, для своевременно оказанной специализированной медицинской помощи, что позволит улучшить дальнейший прогноз данного состояния, в том числе и психологическую адаптацию ребенка в социуме, принимая во внимание, что данная проблема имеет важное значение для каждого ребенка и его семьи.

\section{Выводы}

1. Увеличение количества пациентов с впервые установленным диагнозом ППР центрального генеза в 2020 году можно объяснить активной информационной работой, которая проводится в городе для врачей первичного звена, в том числе, врачей специалистов в амбулаторной сети детских городских поликлиник Департамента здравоохранения города 
Москвы, требующей продолжения для улучшения своевременности, эффективности, качества и доступности профильной медицинской помощи.

2. Требуют продолжения аналитические исследования по данным региональных сегментов Федерального регистра лиц, страдающих жизнеугрожающими и хроническими прогрессирующими редкими (орфанными) заболеваниями, приводящими к сокращению продолжительности жизни граждан или их инвалидности, по пациентам с ППР центрального генеза, в том числе, для верификации более четких критериев прекращения терапии аналогами ГнРГ пролонгированного действия.

Использованная литература:

1. Федеральные клинические рекомендации (протоколы) по ведению детей с эндокринными заболеваниями. Глава: Ведение детей с преждевременным половым развитием. Под общей редакцией И.И. Дедова и В.А. Петерковой, М., 2014: - С. 281; 292. 